\title{
Development versus Adaptation? Facing Climate Change in Ca Mau, Vietnam
}

\author{
Bruno Di Giusto ${ }^{1} \mathbb{D}$, Thi Minh Nghi Le ${ }^{2} \mathbb{D}$, Thanh Thao My Nguyen ${ }^{2} \mathbb{D}$, Thi Thuy Hanh Nguyen $^{2} \mathbb{D}$, \\ Nguyen Uyen My Vu ${ }^{2}$ and Joseph Paul Lavallee ${ }^{2, *(D)}$
}

1 Journalism and Mass Communication Program, Ming Chuan University International College, 250 Zhongshan North Road Section 5, Taipei 111, Taiwan; digiusto@mail.mcu.edu.tw

2 International Business and Trade Program, Ming Chuan University International College, 250 Zhongshan North Road Section 5, Taipei 111, Taiwan; minhnghilt@gmail.com (T.M.N.L.); nguyenthanhthaomy19@gmail.com (T.T.M.N.); thuyhanhnt3003@gmail.com (T.T.H.N.); vunguyenuyenmy@gmail.com (N.U.M.V.)

* Correspondence: lavallee@mail.mcu.edu.tw; Tel.: +886-(02)-2882-4564-x2835

\section{check for} updates

Citation: Giusto, B.D.; Le, T.M.N.; Nguyen, T.T.M.; Nguyen, T.T.H.; Vu, N.U.M.; Lavallee, J.P. Development versus Adaptation? Facing Climate Change in Ca Mau, Vietnam. Atmosphere 2021, 12, 1160. https://doi.org/10.3390/

atmos12091160

Academic Editors: David Reed and Ari Preston

Received: 19 July 2021

Accepted: 3 September 2021

Published: 9 September 2021

Publisher's Note: MDPI stays neutral with regard to jurisdictional claims in published maps and institutional affiliations.

Copyright: (c) 2021 by the authors. Licensee MDPI, Basel, Switzerland. This article is an open access article distributed under the terms and conditions of the Creative Commons Attribution (CC BY) license (https:/ / creativecommons.org/licenses/by/ $4.0 /)$.

\begin{abstract}
Climate change poses a dire threat to the Mekong River Delta, an important supplier of shrimp and rice to global markets. The southernmost province, Ca Mau, is threatened by sea level rise and land subsidence. Little is known of the expected combined impact of these processes, or of the perceptions of farmers towards these threats. This study first projected the combined effects using the most accurate extant elevation data. Next, to assess perceptions, we interviewed 53 farmers from six communes within the province. We found that $43 \%$ of the province could be at risk of submersion by 2030 , and $75 \%$ by 2050 . The interviews revealed that the farmers were largely unaware of the imminence of submersion and did not fully comprehend the nature and magnitude of the underlying processes. Constrained by the requirements of their developmental trajectory, they were focused on short term threats to their livelihood (weather, salinization, pollution). Consequently, far from adapting to the larger threats, they are engaged in practices, such as groundwater extraction for aquaculture, that are hastening the demise of the region. Their plight offers warnings to similar regions around the world. We hope that our findings can inform the development of future outreach programs.
\end{abstract}

Keywords: Mekong River Delta; climate change; sea level rise; land subsidence; aquaculture

\section{Introduction}

Developing countries face the challenge of simultaneously managing economic development and adapting to climate change. Development itself, however, often undermines mitigation and adaptation efforts, a dynamic now playing out in the river deltas of the developing world. These low-lying coastal regions, often vital 'breadbaskets,' trade hubs and homes for large proportions of the population, are highly vulnerable to the effects of sea-level rise. Land subsidence, driven by economic development through groundwater extraction, sand mining and upriver damming, is undermining their sustainability. If these deltas become submerged, developing countries will lose highly productive land and will need to find new living spaces and economic opportunities for the dispossessed inhabitants. While migration of working-age people from rural areas to industrial zones is a typical feature of economic development, with climate change, countries may need to evacuate all residents from threatened areas while trying to sustain development.

The Mekong River Delta (MRD), home to 17.8 million people, has, for the past 30 years, been central to Vietnam's economic development, with steady increases in agricultural productivity and a growing share of the country's export earnings [1]. This low-lying delta is vulnerable to the combined effects of land subsidence (LS) and sea-level rise (SLR), which are generating an overall rate of relative sea rise of 2.1 to $3.6 \mathrm{~cm}$ a year. Absolute 
SLR contributes about $0.33 \mathrm{~cm} /$ year [2,3] and may, on its own, render large parts of the delta uninhabitable between 2050 and 2100 [4-7]. The main driver, however, is LS, caused primarily by groundwater extraction [8] and occurring at rates of between 0.5 and $4 \mathrm{~cm}$ a year in different parts of the delta $[9,10]$. Vietnam thus faces the challenge of sustaining growth while retreating from some regions of the MRD and there is likely "much less time to implement mitigation or adaptation strategies than previously realized" [5,8].

This challenge is especially urgent in the southernmost province of $\mathrm{Ca} \mathrm{Mau}, \mathrm{a}$ lowlying area bordered on two sides by the sea. Ca Mau's farmers may soon face insurmountable difficulties, given that 'hard' adaptation techniques, such as the types of polders used in the Netherlands, are prohibitively expensive [5,11]. It is thus critical to understand both how imminent this threat is and how well-prepared Ca Mau's residents are. In this paper, we first reanalyze existing data to estimate the likely timing and extent of submersion being caused by LS and SLR. Then, we investigate how farmers in the province perceive the threat and intend to respond. Understanding the plight of Ca Mau's farmers offers a window into the future of other regions, both within the MRD and around the world.

\subsection{Economic Development}

The MRD has been central to Vietnam's post-reform trajectory of economic development. The Doi Moi reforms of 1986 initiated a broad shift towards market-oriented production, and subsequent reforms in the late 1990s triggered a rapid transition towards commercial agriculture in the delta. To reach development targets and expand exports, the government provided incentives to farmers to switch from rice to shrimp farming or to intensify existing patterns of shrimp farming, including preferential taxation and financial support, direct subsidies, low-cost loans, and export insurance funds [12]. The economy of the upper delta, rich in freshwater resources, concentrated primarily on freshwater aquaculture and rice cultivation. The central delta, receiving more freshwater than the coastal areas, continued cultivating planted crops, particularly rice, sugarcane and orchards. The coastal and most low-lying regions of the MRD, with more saline soil, led the transition from rice to aquaculture (AQC) farming. They then intensified production, moving from small extensive farms to semi-intensive or intensive farms. From around 2010, they increasingly switched from native giant black shrimp to higher yielding Pacific whiteleg shrimp [13].

The results were dramatic (see Table 1). On only $12.3 \%$ of Vietnam's land, the delta's rice production went from $52 \%$ to 55\% of national production between 1999 and 2017, while aquaculture went from $61 \%$ to $70 \%$ and shrimp went from $72 \%$ to $83 \%$. In less than 20 years, Vietnam has become the world's third largest exporter of both rice and shrimp [14,15].

Table 1. Economic Growth in the MRD and Ca Mau, 1999-2017.

\begin{tabular}{|c|c|c|c|c|c|c|c|}
\hline & & \multicolumn{3}{|c|}{ Mekong River Delta } & \multicolumn{3}{|c|}{ Ca Mau Province } \\
\hline & & 1999 & 2017 & $\begin{array}{c}\% \\
\text { Change }\end{array}$ & 1999 & 2017 & $\begin{array}{c}\% \\
\text { Change }\end{array}$ \\
\hline \multirow[t]{3}{*}{ Rice } & Surface (thousands of ha) & $3,985.2$ & $4,185.3$ & $5.0 \%$ & 243.8 & 113.1 & $-53.6 \%$ \\
\hline & $\begin{array}{c}\text { Yield } \\
\text { (tons } / \text { ha) }\end{array}$ & 4.1 & 5.6 & $37.9 \%$ & 3.5 & 3.9 & $13.9 \%$ \\
\hline & $\begin{array}{l}\text { Production } \\
\text { (millions of tons) }\end{array}$ & 16.3 & 23.6 & $44.9 \%$ & 0.8 & 0.4 & $-47.2 \%$ \\
\hline \multirow[t]{3}{*}{$\mathrm{AQC}$} & $\begin{array}{c}\text { Surface } \\
\text { (thousands of ha) }\end{array}$ & 332.9 & 796.0 & $139.1 \%$ & 141.5 & 302.9 & $114.1 \%$ \\
\hline & Yield (tons /ha) & 886.5 & 3410.8 & $284.8 \%$ & 330.2 & 1017.9 & $208.3 \%$ \\
\hline & Production (millions of tons) & 295.1 & $2,715.0$ & $820.0 \%$ & 46.7 & 308.3 & $560.0 \%$ \\
\hline Shrimp & Production (millions of tons) & 41.4 & 617.7 & $1,392.1 \%$ & 19.7 & 157.7 & $699.5 \%$ \\
\hline
\end{tabular}

Ca Mau province, home to 1.23 million of the delta's 17.8 million people [1], followed a different trajectory than did other parts of the delta. At the end of the 1990s, the government initiated a transition to aquaculture in which: (1) remaining rice farming took place within 
polder systems, imposing high maintenance requirements (dyke/embankment raising and pumping out saline water after floods); (2) aquaculture replaced rice cultivation, forcing farmers to rely on groundwater extraction; and (3) mangrove areas were protected, limiting expansion, and requiring integrated mangrove-aquaculture farming.

Due to higher salinity, freshwater crops (rice, orchards, freshwater eel/fish, bulrush) could only be cultivated within polder systems, surrounded by buffer zones of shrimp-rice rotation agriculture. These polder systems use sluices and pumps to control water levels and to manage saltwater incursions during the flood season. Due to the threat of soil erosion, these systems require constant monitoring and maintenance [16,17].

During the same period, the rest of the province shifted to shrimp aquaculture. With more land available but limited capital to invest, Ca Mau's small farmers opted for extensive shrimp farming with its lower initial investment costs (about $2.5 \%$ those of intensive farming [18]). Lower freshwater flows and less frequent flooding, due to the distance of this region from the distributaries of the Mekong River, also hindered intensification by making wastewater more difficult to discharge. Finally, along the southeast coast, restrictions to protect mangroves further limited intensification. Although intensification levels remain lower than in most of the delta, some intensification has occurred through a switch to whiteleg shrimp. Even here, however, farming of giant tiger prawn persists along the coast with its protected mangrove regions and higher salinity levels $[13,19]$.

In $\mathrm{Ca} \mathrm{Mau}$, total surface area for rice production declined dramatically and gave way to a massive increase in AQC (see Figure 1). At the same time, because of the predominance of extensive AQC, the yield and overall production of shrimp increased more slowly than in the rest of the delta. Nonetheless, Ca Mau's agrarian sector has experienced rapid development over the past two decades (see Table 1).

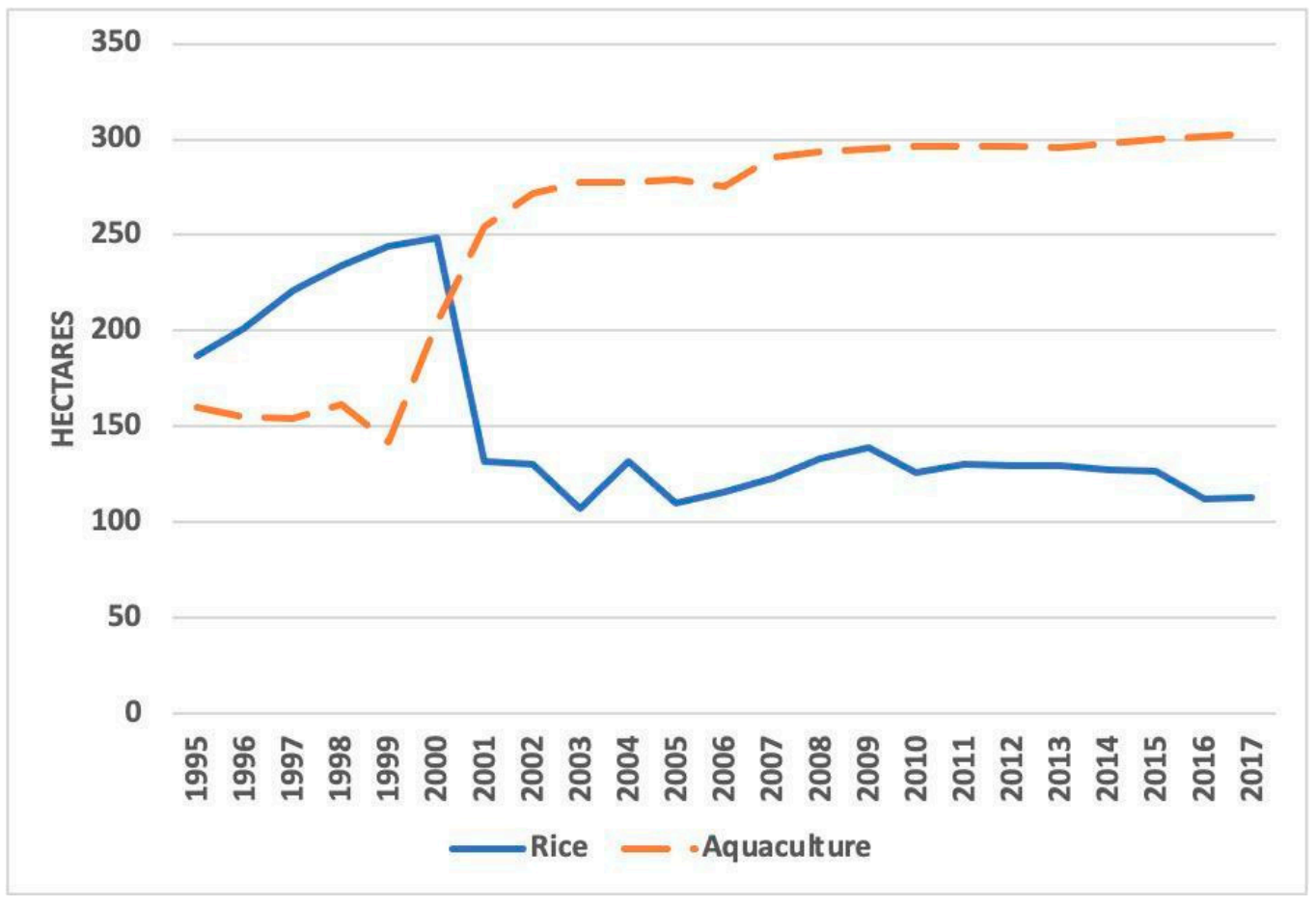

Figure 1. Use of agricultural land in Ca Mau Province, 1995-2017. Notice the sharp pivot between 1999 and 2002 induced by government incentives to shift production from rice to aquaculture (Decree 09/2000/NQ-CP) [20].

\subsection{Threats-SLR and LS}

This developmental trajectory, however, faces severe threats. In addition to yield loss from environmental degradation caused by new intensive farming methods [13], increasingly volatile weather caused by climate change has brought more frequent drought, 
flooding, storm surge and salinization, all particularly threatening for rice growing within polder systems [21,22]. Nonetheless, the gravest threat to sustainability is relative SLR: with an average elevation of $0.59 \mathrm{~m}$-compared to an average of $0.82 \mathrm{~m}$ for the entire delta [5] - submersion is an imminent danger. In southern Vietnam, $25 \mathrm{~cm}$ of SLR relative to 2005 is expected by 2050 [6]. This estimate does not capture possible feedbacks in the Antarctic, which could cause SLR of $60 \mathrm{~cm}$ or above by $2050[3,23]$.

Land subsidence in the MRD is occurring even more rapidly, with an average of $1.1 \mathrm{~cm}$ of subsidence for 2006 to 2010 per year [24], increasing to more than $1.6 \mathrm{~cm}$ per year for the southern delta [9]. The causes of LS in Ca Mau province include urbanization and industrialization in the province (the highest rate of LS in the delta $-4 \mathrm{~cm}$ per yearis occurring in Ca Mau city), as well as groundwater extraction for aquaculture [8,9]. Groundwater extraction is not allowed for rice cultivation [24] but is critical for semiintensive and intensive aquaculture. The transition to whiteleg shrimp allowed for more intensive farming, as whiteleg shrimp grow faster and tolerate a higher density within a single pond. However, higher densities require artificial feeding, increasing water eutrophication and disease risk. This meant that farmers needed a greater flow of fresh water to eliminate waste, obtainable only through pumping groundwater [25], increasing the rate of LS.

How soon will these two forces, SLR and LS, impact farming in the province? Estimating the timing of relative sea rise is difficult. First, due to currents, wind and temperature variations, sea surface height and so on, local rates of SLR vary globally [5]. Second, the speed, extent and duration of LS depend largely on rates of sediment accretion and the nature of surface activities (urbanism, agriculture, aquaculture, etc.) $[9,10,25]$. Third, most studies predict nonlinear rates of SLR and LS-increasing for SLR [3] and decreasing for LS [8] (although current trends may persist over decades if groundwater extraction continues at present levels [10]). Finally, uncertainty arises from the topographical measures employed. Most digital elevation models (DEMS) in the MRD rely on measures obtained from satellites, such as the Shuttle Radar Topography Mission (STRM DEM). Such global DEMs have a standard vertical accuracy of about two or more meters, an accuracy range that is greater than the predicted global mean SLR for this century [4,5,26,27]. More accurate measurements using airborne LiDAR are seldom available for developing countries. This has prompted researchers to provide corrective measures to global DEMs, such as the use of manual corrections in the Multi-Error-Removed Improved-Terrain (MERIT) DEM [28] or AI correction in the CoastalDEM [4]. While such corrections are important, they are rarely validated against absolute elevation measurements in the field using a local datum referenced to sea-level height $[5,26]$. Thus, the first goal of this paper is to estimate the timing of relative SLR in Ca Mau province using the most recent and most accurate digital elevation model (decimeter accuracy; [5]).

\subsection{Perceptions and Responses}

Much research on climate change adaptation assumes that local actors are well positioned to accurately assess the threats they face and that this risk perception leads to adequate local responses $[29,30]$. Some researchers have emphasized local, 'experiential' knowledge and farmer-led innovations [31] in responding to climate change. The situation in Ca Mau calls these perspectives into question. Land subsidence may be uniquely difficult to perceive and respond to, as the process itself is not observable and its manifestations (longer flood seasons, stronger salinization effects) can easily be attributed to other causes, such as SLR and extreme weather. For these reasons, it may be challenging for local communities to connect these symptoms to the LS caused, in part, by their own farming practices.

While most research [11,29-32] has focused on communities living in the central MRD or along the distributaries of the Mekong River, it is Ca Mau province that is on the 'front line' of climate change impacts. Ca Mau's farmers must adapt to both governmentimposed constraints (extensive or semi-intensive AQC in highly saline environments or 
rice growing within vulnerable polder systems) and ecological conditions (low topography, high salinization, coastal areas distant from sources of surface freshwater, higher land subsidence). The threats they face and their responses to these threats may offer insights into what is likely to unfold in the rest of the delta, if decisionmakers there make similar economic choices. It is thus critical to grasp how the farmers in Ca Mau perceive these threats and how they plan to respond.

The perception of risks held by scholars studying a region may bear little resemblance to those held by the farmers pursuing their livelihood strategies within the same region. In this paper, we investigate the capacity of local farmers to accurately assess the threats they face. To explore the salience of the objective risks of LS and SLR emphasized by outside experts, we sought first to identify the problems that farmers themselves raised before inquiring about their perception of SLR and LS.

This study therefore seeks to answer the following questions:

1. What is the likely timing of threats posed by the combined effects of SLR and LS?

2. What environmental changes are most salient to farmers? Which changes are perceived as threatening? Which changes are they making adaptive responses to?

\section{Materials and Methods}

Ca Mau province is bordered by the Gulf of Thailand and the South China Sea. The west and center of the province are lowest in elevation, while the southeast coast has a ridge of higher elevation and a protected mangrove belt. The province includes three broad ecozones [33], as shown in Figure 2a below: (1) The northern eco-zone, with a mixture of forests, rice and aquaculture sites, contains a polder system with freshwater agriculture, and a protected Melaleuca forest; (2) The northeastern eco-zone, characterized by moderate flooding and high salinity (with the exception of a smaller polder system near the city of $\mathrm{Ca} \mathrm{Mau}$ ); and (3) The southern eco-zone, characterized by high salinity but fewer large rivers and less flooding. Soil salinity is a major issue in the northeastern and southern ecozones, with levels reaching a maximum above $25 \mathrm{~g} / \mathrm{L}$ during the dry season [2]. The soil in Ca Mau is highly saline for most of the year, aside from the autumn wet season [34]. Due to its distance from the Mekong River, less than $1 \%$ of the province is at risk of fluvial flooding [34,35]; we therefore did not include this risk in this study.The province's densest population clusters occur around Ca Mau city and in the west coast city of Song Doc. The southeastern part of the province, with higher salinity rates and a coastal mangrove buffer, is relatively sparsely populated (Figure $2 b$ ).

\subsection{Elevation Projections, Ca Mau Province}

We incorporate the most recent and accurate elevation model for the MRD, a topographical digital elevation model (Topo DEM) based on a national 2014 dataset of nearly 20,000 elevation points in the Mekong Delta (scale 1:200,000) [5]. This model does not include bedrock outcrops and rivers. The Topo DEM data (Figure 2c) is vertically referenced to Vietnam's geodetic Hon Dau datum. All transformations were conducted using the spatial reference WGS_1984_UTM_Zone_48N.

We first digitized the 2015 ICEM compaction-based subsidence rate map for the delta [36] (these values are consistent with the most recent direct measurements [10]). Next, we projected its geographic coordinates to match those of the Topo DEM (see Figure 2d, showing local compaction rates within Ca Mau province; [9]). We then generated the projected 2030 and 2050 elevations for each $500 \times 500$ land grid of Ca Mau province in the original 2014 TopoDEM base layer by subtracting from it the rasters representing the various scenarios for LS in 2030 and 2050 (see Supplementary Figure S1). These rasters were created using the digitized map (Figure 2d) and the estimated LS values. Estimates for LS for 2030 and 2050 were obtained by starting with 2014 as our baseline year [5] and multiplying the annual compaction rate of each compaction zone (see Figure $2 \mathrm{~d}$ ) by 16 and 36 , respectively. 

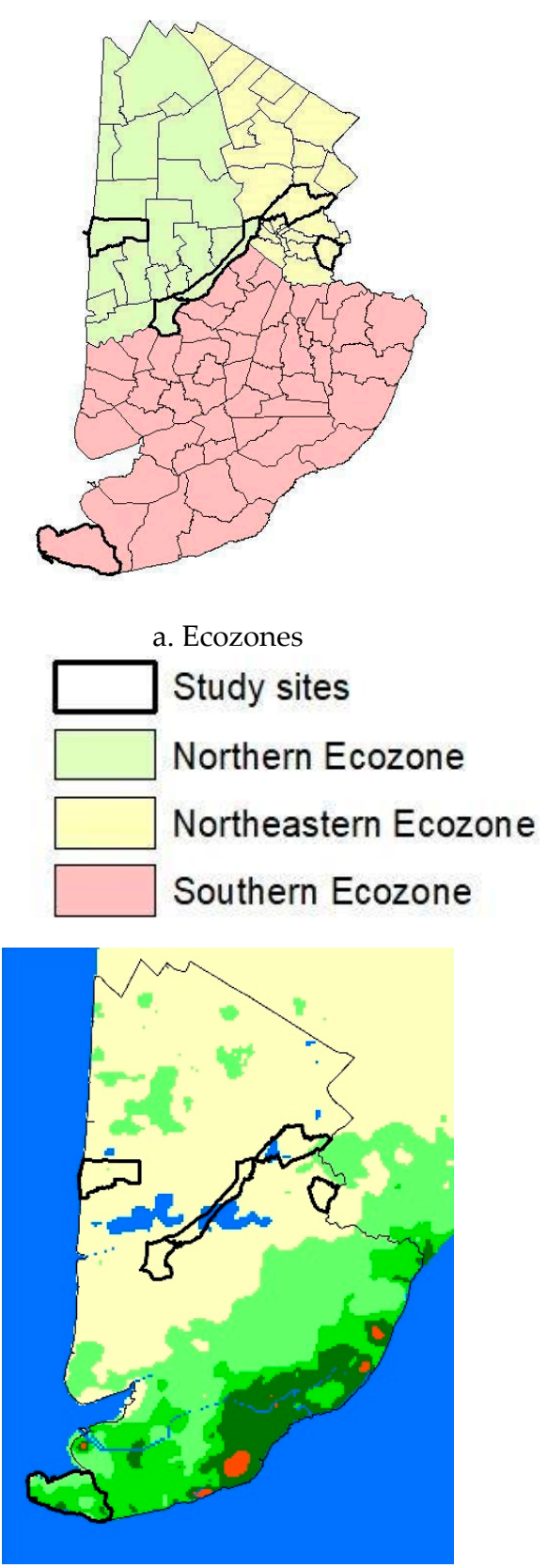

c. Elevation in Meters, 2014

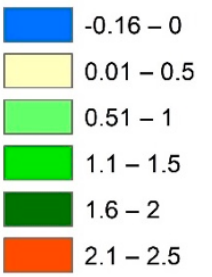

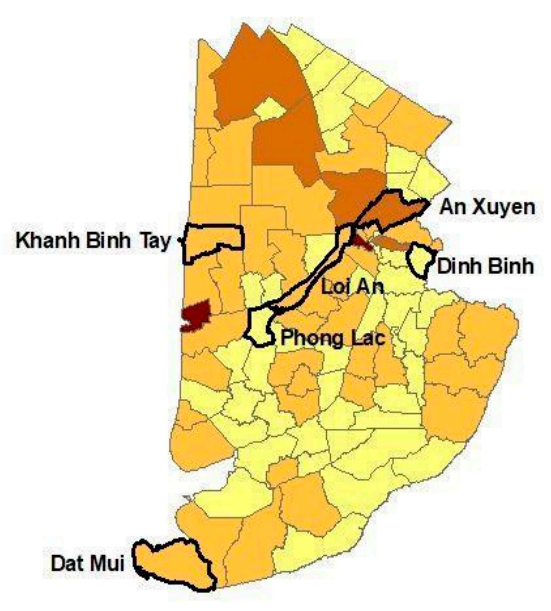

b. 2014 Population of Communes
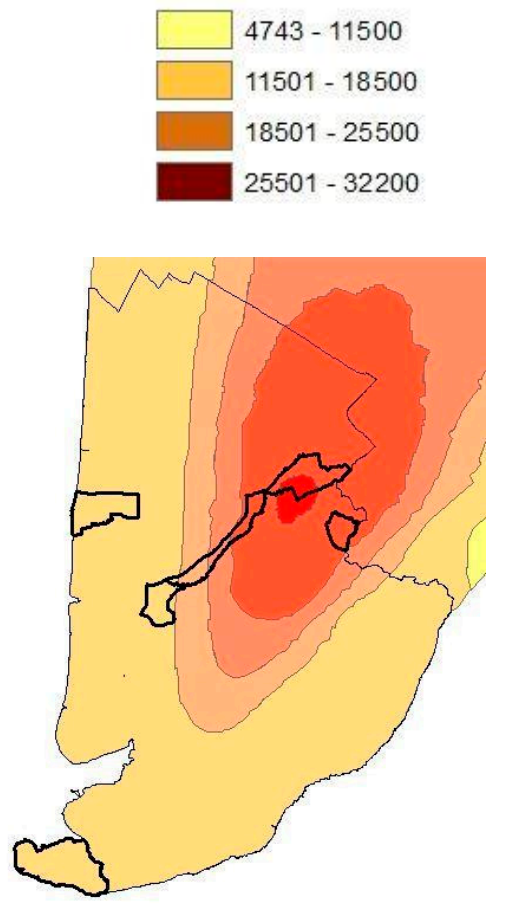

d. Annual Land Subsidence Rate in $\mathrm{Cm}$

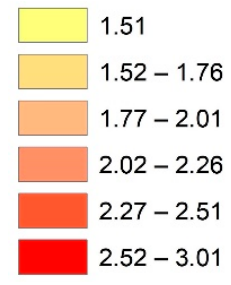

Figure 2. (a) Study sites within Ca Mau's three eco-zones: (1) The northeastern eco-zone (yellow), characterized by moderate flooding and high salinity, contains An Xuyen and Dinh Binh, both in the Ca Mau City district; (2) the northern eco-zone (green) is characterized by a mixture of forests, rice and aquaculture sites and contains the study sites of Khanh Binh Tay, Loi An and Phong Lac; (3) the southern eco-zone (pink), characterized by high salinity but fewer large rivers and less flooding, contains the study site of Dat Mui 34]. (b) 2014 population by commune; (c) Elevation in meters and location of tidal gauge stations in Ca Mau province, adapted from TopoDEM [5]. (d) Land subsidence rates are low range estimates derived from annual averages over the 2006-2010 period $[9,36]$. 
We next generated values based on mean sea level [37,38]. For expected SLR to 2030, we used the estimate of $3.3 \mathrm{~mm}$ annually from 2014 to 2030, which is based on the average increase over the 1993-2010 period [3]. To account for expected non-linear acceleration in subsequent years, we began with the Vietnamese government's estimate of $25 \mathrm{~cm}$ of SLR for southern Vietnam by 2050, relative to the 1986-2005 period, based on the RCP 8.5 scenario [6]. We then subtracted $2.97 \mathrm{~cm}$ to account for the $3.3 \mathrm{~mm}$ yearly between 2005 and 2014, arriving at an estimate of $22 \mathrm{~cm}$ above the 2014 baseline. We then used GIS raster calculator tools (map algebra with conditional statements) to create inundation depth rasters to represent the extent of coastal flooding for areas adjacent to the ocean (see Supplementary Figure S2). Finally, using the ArcGIS zonal tool, we calculated the total submerged surfaces and thus the percentage of our communes and the entire province threatened with submersion. All calculations and transformations were performed with ArcGIS 10.8.1 using the Spatial Analyst extension.

\subsection{Qualitative Interviews in Six Communes}

\subsubsection{Background and Goals}

The purpose of the survey was to explore the subjective perceptions of the farmers concerning threats to their livelihood and the dangers posed by sea level rise and land subsidence.

\subsubsection{Research Sites and Participants}

Interviews with a non-representative, convenience sample of 53 farmers were conducted in Ca Mau district, An Xuyen $(n=12)$ and Dinh Binh $(n=10)$ communes; Tran Van Thoi district, Khanh Binh Tay $(n=11)$, Loi An $(n=6)$ and Phong Lac $(n=4)$ communes; and Ngoc Hien district, Dat Mui commune $(n=10)$. Commune locations are shown in Figure 2.

\subsubsection{Interview Materials and Procedures}

A questionnaire that included demographic questions and both closed and openended questions related to threats to their farming practices were drafted in the fall of 2017 and pre-tested on a small number of acquaintances (all farmers in the Mekong River Delta) for clarity and relevance, resulting in minor changes in the final version. Demographic questions included age, gender, type of farming (e.g., aquaculture, rice farming), farmers' status (owner, renter, laborer) and farm size, and were followed by 15 questions covering awareness, risk perception, knowledge, and adaptation to environmental changes. In terms of environmental changes, we first asked farmers about any changes in their fields that they had noticed, with no further specification or prompting. After they had responded, we asked three questions related to LS and SLR: (1) whether they had heard of SLR and LS, (2) whether they had observed any effects in their fields, and (3) whether they could explain their causes. To measure risk perception, we asked how threatening perceived changes were to their farming practices and to their income, using a five-point Likert scale ( $1=$ no threat; $5=$ extremely threatening). Finally, we asked whether they had made any adaptations to cope with these changes. English/Vietnamese versions of the questionnaire are in the supplementary file (Supplementary Materials 3). The interviews were conducted in Vietnamese during the harvest season in January 2018. Farmers were approached directly in their household or fields. Each interview took approximately $30 \mathrm{~min}$ and was recorded. Responses were transcribed, translated into English, categorized and coded for analysis.

\subsubsection{Statistical Analysis}

Differences across groups (primarily communes) were evaluated with Mann-Whitney $\mathrm{U}$ tests and Kruskal-Wallis $\mathrm{H}$ tests, as the data did not meet the assumptions of the parametric alternatives; Fisher Exact Tests were used because expected cells sizes were below five. The Wilcoxon signed-rank test was used to rank relative degree of concern for SLR, LS and observed changes in fields. Chi Square linear trend tests were used to evaluate 
the relationship between risk perception and adaptation for LS and SLR. All analyses were conducted using IBM SPSS v. 20.

\section{Results}

\subsection{Objective Risks}

Table 2 shows estimates for LS and SLR by 2030 and 2050 for each commune and for the entire province. Figure 3 shows elevation projections for Ca Mau province for 2030 and 2050 based on projections of LS alone, LS and SLR at mean sea level. As can be seen, the effects of LS are projected to be greater than those of SLR. The combined effects are most concerning, however. Except for Dat Mui, 87.1 to 100\% of the land within the remaining five communes is likely to be below mean sea level by 2030 . Further, this rises to $100 \%$ for these five communes by 2050. For all of Ca Mau province, these figures are $43.4 \%$ by 2030 and $75.4 \%$ by 2050 .

Table 2. Topography and forecasts for SLR and LS in 2030 and 2050, by commune.

\begin{tabular}{|c|c|c|c|c|c|c|c|}
\hline & Dat Mui & Dinh Binh & $\begin{array}{l}\text { Kanh Binh } \\
\text { Tay }\end{array}$ & An Xuyen & Phong Lac & Loi An & CA MAU \\
\hline Area in hectares & 10.173 & 2294 & 5859 & 5784 & 3291 & 4637 & 511.146 \\
\hline $\begin{array}{c}\text { Elevation } \\
\mathrm{cm}(\mathrm{SD})\end{array}$ & $103(21)$ & $29(6)$ & $25(6)$ & $16(18)$ & $26(5)$ & $13(12)$ & $\begin{array}{c}59 \\
(48)\end{array}$ \\
\hline Elevation min-max in $\mathrm{cm}$ & $45-186$ & $16-45$ & $14-51$ & $-8-62$ & $16-39$ & $-7-40$ & $-16-259$ \\
\hline LS in cm yrly & $1.76-2$ & $2.5-3$ & $1.76-2$ & $2.5-3.3$ & $1.76-2$ & $2.01-3$ & $1.76-3.3$ \\
\hline SLR in cm yrly & 0.33 & 0.33 & 0.33 & 0.33 & 0.33 & 0.33 & 0.33 \\
\hline \multicolumn{8}{|l|}{2030 * } \\
\hline $\mathrm{LS}$ in $\mathrm{cm}$ & 28.2 & 40 & 28.2 & 40 & 28.2 & 32.2 & 28.2 \\
\hline SLR in $\mathrm{cm}$ & 5.3 & 5.3 & 5.3 & 5.3 & 5.3 & 5.3 & 5.3 \\
\hline Total in $\mathrm{cm}$ & 33.5 & 45.3 & 33.5 & 45.3 & 33.5 & 37.5 & 33.5 \\
\hline \% below mean sea level * & $0.0 \%$ & $100 \%$ & $90.6 \%$ & $97.8 \%$ & $92.4 \%$ & $87.1 \%$ & $43.4 \%$ \\
\hline \multicolumn{8}{|l|}{$2050 *$} \\
\hline $\mathrm{LS}$ in $\mathrm{cm}$ & 63.4 & 90.0 & 63.4 & 90 & 63.4 & 72.4 & 63.4 \\
\hline SLR in $\mathrm{cm}$ & 22 & 22 & 22 & 22 & 22 & 22 & 22 \\
\hline Total in $\mathrm{cm}$ & 85.4 & 112 & 85.4 & 112 & 85.4 & 94.4 & 85.4 \\
\hline$\%$ below mean sea level & $13.3 \%$ & $100 \%$ & $100 \%$ & $100 \%$ & $100 \%$ & $100 \%$ & $75.4 \%$ \\
\hline
\end{tabular}

* Note: Estimates are conservative, with LS by 2030 and 2050 in each commune calculated using the low end for the range of LS currently occurring within the commune (rates are derived from the annual averages over the 2006-2010 period, [9,36]). Estimates for 2030 were calculated by multiplying this figure by 16, representing the years from 2014 to 2030; estimates for 2050 were derived by multiplying the figure by 36. The estimate of $3.3 \mathrm{~mm}$ of SLR annually to 2030 is from the IPCC [3]. As SLR is expected to rise in a non-linear manner, we used the estimate of total sea level rise of $22 \mathrm{~cm}$ by 2050 based onVietnamese government data ([6]; see Section 2.1 above). For the entire province of $\mathrm{Ca} \mathrm{Mau}$ (rightmost column), we used the lowest subsidence rates found in our sample of communes.

\subsection{Interview Results}

\subsubsection{Demographic Results}

Table 3 summarizes the demographic results. The average age was about 50 years old, $72 \%$ were male, and all but one owned their own land, with average land size being about 3 ha. There were no significant differences by commune in age (Kruskal-Wallis, $p=0.205$ ) or farm size (Kruskal-Wallis, $p=0.154$ ). About $23 \%$ of the farmers were growing rice and/or other land crops within a polder system; $55 \%$ were aquaculture farmers and $22 \%$ had mixed aquaculture and land crops. As shown in the table, a wide variety of farm types were reported; explanations for the abbreviations used in the table are provided in the notes below it. 

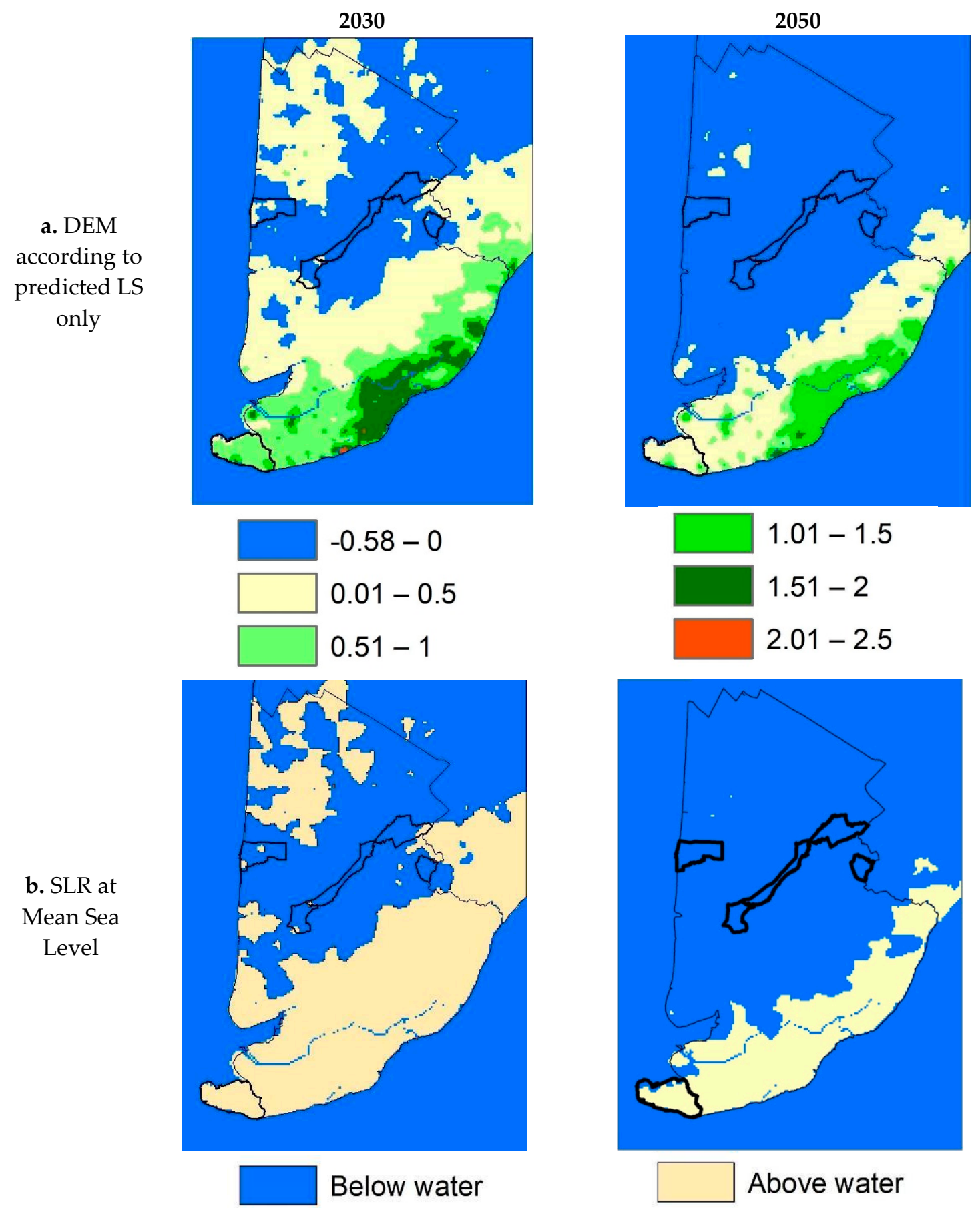

Figure 3. Ca Mau province elevation projections for 2030 and 2050, based on (a) land subsidence only; and (b) land at risk of submersion due to land subsidence and sea level rise at Mean Sea Level (MSL. Measurements are in meters in relation to sea level (Hon Dau 1992 datum).

\subsubsection{Environmental Changes (Unprompted): Salience}

In response to the question "Have you noticed any changes in your fields," fifty two of the 53 farmers report having observed some change. Table 4 summarizes their responses. When not specifically asked, only $9.4 \%$ of farmers report having observed SLR and only $3.8 \%$ report having observed LS. Farmers were mainly concerned with changes in the frequency and magnitude of weather fluctuations, saline intrusion, and water pollution. The top seven concerns (erratic weather, saline intrusion, water pollution, soil infertility, diseases, flooding, insects) emerged directly from day-to-day farming practices and only 
saline intrusion and flooding appear related to LS and SLR. The rightmost column provides abbreviated descriptions of the changes reported by farmers.

Table 3. Sample characteristics by commune.

\begin{tabular}{|c|c|c|c|c|c|c|c|}
\hline Commune & $\begin{array}{l}\text { An Xuyen } \\
(n=12)\end{array}$ & $\begin{array}{l}\text { Dinh Binh } \\
\quad(n=10)\end{array}$ & $\begin{array}{l}\text { Dat Mui } \\
(n=10)\end{array}$ & $\begin{array}{c}\text { Khanh Binh } \\
\text { Tay } \\
(n=11)\end{array}$ & $\begin{array}{l}\text { Loi An } \\
(n=6)\end{array}$ & $\begin{array}{l}\text { Phong Lac } \\
\qquad(n=4)\end{array}$ & $\begin{array}{c}\text { Total } \\
(n=53)\end{array}$ \\
\hline Age & 53.75 (9.19) & $51.00(9.63)$ & $50.70(11.41)$ & 48.09 (9.84) & $49.5(14.2)$ & 37.75 (8.66) & $\begin{array}{c}49.8 \\
(10.7)\end{array}$ \\
\hline Gender & $\begin{array}{c}\mathrm{M}=10 \\
\mathrm{~F}=2\end{array}$ & $\mathrm{M}=8 ; \mathrm{F}=2$ & $\begin{array}{c}M=8 \\
F=2\end{array}$ & $\begin{array}{c}M=7 \\
F=4\end{array}$ & $\begin{array}{c}M=3 \\
F=3\end{array}$ & $\begin{array}{c}M=2 \\
F=2\end{array}$ & $\begin{array}{c}\mathrm{M}=38 \\
\mathrm{~F}=15\end{array}$ \\
\hline $\begin{array}{l}\text { Farmer } \\
\text { Status }\end{array}$ & $\begin{array}{c}\text { Owner = } 10 \\
\text { Owner \& } \\
\text { Renter = } 1 \\
\text { Renter \& } \\
\text { Laborer = } 1\end{array}$ & Owner $=10$ & Owner $=10$ & $\begin{array}{c}\text { Owner }=10 \\
\text { Owner \& } \\
\text { Renter }=1\end{array}$ & Owner $=6$ & Owner = 4 & $\begin{array}{c}\text { Owner }=50 \\
\text { Owner } / \\
\text { Renter }=2 \\
\text { Renter / } \\
\text { Laborer = } 1\end{array}$ \\
\hline Farm Type ** & $\begin{array}{c}\text { R-SAQC = } 6 \\
\text { SAQC }=1 \\
\text { R/O = 4 } \\
\text { Orchards = } 1\end{array}$ & $\mathrm{SAQC}=10$ & $\mathrm{ISM}=10$ & $\begin{array}{c}\mathrm{R} / \mathrm{O}=7 \\
\mathrm{R}-\mathrm{FAQC}=3 \\
\mathrm{R}-\mathrm{SAQC}=1\end{array}$ & $\begin{array}{c}\mathrm{SAQC}=4 \\
\mathrm{RSR}=2\end{array}$ & $\mathrm{SAQC}=4$ & $\begin{array}{c}\text { SAQC = } 19 \\
\text { R/O = 11 } \\
\text { ISM = } 10 \\
\text { R-SAQC = 9 } \\
\text { RSR = 2 } \\
\text { Orchards = 1 } \\
\text { R/SWAQC = } \\
1\end{array}$ \\
\hline $\begin{array}{l}\text { Farm Size } \\
\quad(\mathrm{Ha}) \\
\text { Mean (SD) }\end{array}$ & $\begin{array}{l}3.04 \text { ha } \\
\text { (3.86 ha) }\end{array}$ & $\begin{array}{l}2.67 \mathrm{ha} \\
\text { (1.73 ha) }\end{array}$ & $\begin{array}{l}4.31 \text { ha } \\
\text { (2.93 ha) }\end{array}$ & $\begin{array}{l}2.73 \text { ha } \\
\text { (1.04 ha) }\end{array}$ & $\begin{array}{l}2.48 \text { ha } \\
\text { (1.02 ha) }\end{array}$ & $\begin{array}{l}2.12 \text { ha } \\
(0.63 \text { ha })\end{array}$ & $\begin{array}{l}3.02 \text { ha } \\
\text { (2.44 ha) }\end{array}$ \\
\hline
\end{tabular}

* Other small crops were typically grown with rice, including bulrush. ${ }^{* *}$ Types included: $\mathrm{R} / \mathrm{O}=$ Rice and other; $\mathrm{R}-\mathrm{FAQC}=\mathrm{Rice}$ and freshwater AQC; RSR = Rice-Shrimp Rotation; R/SWAQC = Rice \& saltwater AQC; SAQC = Shrimp aquaculture (white leg shrimp) in brackish water; ISM = Integrated shrimp-mangrove (giant tiger prawn with mud crabs).

Table 4. Observed changes to fields and crops (unprompted and prompted). Rows in grey display the two foci of our study; they are highlighted to emphasize their low salience for farmers.

\begin{tabular}{cccc}
\hline Reported Changes & $\begin{array}{c}\text { Farmers Reporting } \\
\text { Change } \\
\text { (Initial, Unprompted) }\end{array}$ & $\begin{array}{c}\text { Percent of Farmers } \\
\text { Reporting Change } \\
\text { (Prompted) }\end{array}$ & Details of Observed Changes \\
\hline Erratic/Extreme Weather & $88.7 \%$ & $\begin{array}{c}\text { Extended rainy season/high } \\
\text { precipitation; higher precipitation in dry } \\
\text { season, unpredictable seasonal changes, } \\
\text { weather and temperature; storms, hotter } \\
\text { weather, drought, temperature decreases }\end{array}$ \\
\hline Saline Intrusion & $35.8 \%$ & $\begin{array}{c}\text { Faster saline intrusion, saline water is } \\
\text { higher, higher salinity levels }\end{array}$ \\
\hline Water Pollution & $20.8 \%$ & $35.8 \%$ & Water pollution from industrial farming \\
\hline Soil Infertility & $17.0 \%$ & $22.6 \%$ & Barren, infertile soil \\
\hline Diseases & $13.2 \%$ & $17.0 \%$ & $\begin{array}{c}\text { Many kinds of diseases affecting shrimp } \\
\text { and plants; more bacteria in fields }\end{array}$ \\
\hline Flooding & $9.4 \%$ & $20.8 \%$ & Higher water level, inundation \\
\hline Insects & $9.4 \%$ & $17.0 \%$ & Harmful insects; insects spreading \\
diseases
\end{tabular}

* The reported percentages for 'prompted' changes were compiled from changes reported as responses to all questions in the interview. 


\subsubsection{Awareness and Understanding of SLR and LS}

Table 5 summarizes results for awareness and understanding of SLR and LS. When asked directly, $90.6 \%$ of farmers ( 48 of 53 ) had heard of SLR but only $68 \%$ ( 36 of 53 , or $75 \%$ of those who had heard of it) had observed it in their own fields (for all reported results, no statistically significant differences occurred across communes, unless specifically mentioned). Only $39.6 \%$ of all farmers ( 21 of 53 ) could correctly state its causes and this did not differ significantly between those who reported observing SLR (of the 36 who observed, 13 understood; of the 17 who hadn't observed, 4 understood; Fisher's Exact Test, $p=0.530$ ).

Table 5. Knowledge.

\begin{tabular}{|c|c|c|c|c|c|c|c|}
\hline & $\begin{array}{c}\text { An } \\
\text { Xuyen } \\
(n=12)\end{array}$ & $\begin{array}{c}\text { Dinh } \\
\text { Binh } \\
(n=10)\end{array}$ & $\begin{array}{c}\text { Dat } \\
\text { Mui } \\
(n=10)\end{array}$ & $\begin{array}{l}\text { Khanh } \\
\text { Binh Tay } \\
(n=11)\end{array}$ & $\begin{array}{l}\text { Loi An } \\
(n=6)\end{array}$ & $\begin{array}{c}\text { Phong } \\
\text { Lac } \\
(n=4)\end{array}$ & $\begin{array}{l}\text { TOTAL } \\
(n=53)\end{array}$ \\
\hline \multicolumn{8}{|l|}{ SLR } \\
\hline Heard of & 9 & 10 & 10 & 11 & 5 & 3 & 48 \\
\hline Observed & 8 & 8 & 7 & 7 & 3 & 3 & 36 \\
\hline Understand * & 3.5 & 6.5 & 3.5 & 3.5 & 2 & 2 & 21 \\
\hline \multicolumn{8}{|l|}{ LS } \\
\hline Heard of & 9 & 7 & 10 & 11 & 4 & 3 & 44 \\
\hline Observed & $0^{\mathrm{a}}$ & 0 & $6^{a}$ & 4 & 1 & 1 & 12 \\
\hline Understand * & 2 & 3.5 & 3.5 & 5 & 3 & 0.5 & 17.5 \\
\hline
\end{tabular}

For LS, $83 \%(44 / 53)$ had heard of it but only 12 of the $44(27.3 \%)$ who had heard of it reported having observed it. Only $33 \%$ of all farmers (18 of 53) could correctly state the causes of LS and this did not differ between those who did and did not report personal observations (of the 12 who observed, 4 understood; of the 41 who had not observed, 15 understood; Fisher's Exact Test, $p=1.000$ ).

Respondents in Dat Mui were significantly more likely to report having observed LS and respondents in An Xuyen significantly less likely to do so (Fisher's Exact Test = 14.8, $p=0.003$ ). This is an inversion of the expected results, given that An Xuyen has the highest rate of LS in our study (Figure 2d). When farmers reported not having observed it, they often also added comments such as "it doesn't happen here" or "it happens elsewhere", often specifying that it happens "along the coast." This suggests that they may be confusing LS with the land erosion occurring along the coast.

\subsubsection{Risk Perception and Adaptation for All Changes}

Results for perceived risk and adaptation are shown in Table 6. A gradient from high to low levels of concern, established with a series of Wilcoxon signed-rank tests, showed the same pattern as in Table 4, running from changes the farmers reported on their own, to SLR and then LS. This was true for both threats to their farming practices (LS-SLR, $p=0.000, \mathrm{~W}=-4.185 ; \mathrm{OC}-\mathrm{LS}, p=0.000, \mathrm{~W}=5.833$; SLR-OC, $p=0.000, \mathrm{~W}=-3.789$ ) and threats to income (LS-SLR, $p=0.000, \mathrm{~W}=-4.231$; OC-LS, $p=0.000, \mathrm{~W}=5.569$; SLR-OC, $p=0.002, W=-3.13)$. The same order can be seen in the percentage of farmers reporting adaptations to these broad threats (Table 6). Overall, 41 of 53 farmers reported making adaptations. 
Table 6. Risk perception and adaptation.

\begin{tabular}{|c|c|c|c|c|c|c|c|}
\hline & $\begin{array}{c}\text { An } \\
\text { Xuyen } \\
(n=12)\end{array}$ & $\begin{array}{c}\text { Dinh } \\
\text { Binh } \\
(n=10)\end{array}$ & $\begin{array}{c}\text { Dat } \\
\text { Mui } \\
(n=10)\end{array}$ & $\begin{array}{c}\text { Khanh } \\
\text { Binh Tay } \\
(n=11)\end{array}$ & $\begin{array}{l}\text { Loi An } \\
(n=6)\end{array}$ & $\begin{array}{l}\text { Phong } \\
\text { Lac } \\
(n=4)\end{array}$ & $\begin{array}{l}\text { TOTAL } \\
(n=53)\end{array}$ \\
\hline \multicolumn{8}{|l|}{$\begin{array}{l}\text { All Observed } \\
\text { Changes }\end{array}$} \\
\hline $\begin{array}{c}\text { Risk to Farming } \\
\text { Practices } \\
\text { M (SD) }\end{array}$ & $\begin{array}{c}3.25 \\
(1.60)\end{array}$ & $\begin{array}{c}2.90 \\
(1.37)\end{array}$ & $\begin{array}{c}3.80 \\
(0.92)\end{array}$ & $\begin{array}{c}3.64 \\
(1.36)\end{array}$ & $\begin{array}{c}3.33 \\
(1.51)\end{array}$ & $\begin{array}{c}2.75 \\
(1.26)\end{array}$ & $\begin{array}{c}3.34 \\
(1.34)\end{array}$ \\
\hline $\begin{array}{l}\text { Risk to Income } \\
\text { M (SD) }\end{array}$ & $\begin{array}{c}3.33 \\
(1.67)\end{array}$ & $\begin{array}{c}2.70 \\
(1.64)\end{array}$ & $\begin{array}{c}4.10 \\
(0.88)\end{array}$ & $\begin{array}{c}3.36 \\
(1.57)\end{array}$ & $\begin{array}{c}3.33 \\
(1.51)\end{array}$ & $\begin{array}{c}2.75 \\
(1.26)\end{array}$ & $\begin{array}{c}3.32 \\
(1.48)\end{array}$ \\
\hline Percentage adapting & $58 \%$ & $70 \%$ & $40 \%$ & $64 \%$ & $83 \%$ & $25 \%$ & $58 \%$ \\
\hline \multicolumn{8}{|l|}{ SLR } \\
\hline Objective Risk ** & $\begin{array}{l}\text { Very } \\
\text { High }\end{array}$ & High & High & $\begin{array}{l}\text { Very } \\
\text { High }\end{array}$ & High & High & \\
\hline $\begin{array}{c}\text { Risk to Farming } \\
\text { Practices } \\
\text { M (SD) }\end{array}$ & $\begin{array}{c}2.00 \\
(1.65)\end{array}$ & $\begin{array}{c}1.20 \\
(0.42)\end{array}$ & $\begin{array}{c}3.50 \\
(1.78)\end{array}$ & $\begin{array}{c}3.09 \\
(1.70)\end{array}$ & $\begin{array}{c}2.00 \\
(1.55)\end{array}$ & $\begin{array}{c}1.25 \\
(0.50)\end{array}$ & $\begin{array}{c}2.30 \\
(1.65)\end{array}$ \\
\hline $\begin{array}{c}\text { Risk to Income } \\
\text { M (SD) }\end{array}$ & $\begin{array}{c}2.00 \\
(1.65)\end{array}$ & $\begin{array}{c}1.40 \\
(0.97)\end{array}$ & $\begin{array}{c}3.50 \\
(1.78)\end{array}$ & $\begin{array}{c}3.41 \\
(1.59)\end{array}$ & $\begin{array}{c}2.00 \\
(1.55)\end{array}$ & $\begin{array}{c}1.75 \\
(1.50)\end{array}$ & $\begin{array}{c}2.44 \\
(1.69)\end{array}$ \\
\hline Percentage adapting & $42 \%$ & $40 \%$ & $70 \%$ & $45 \%$ & $33 \%$ & $25 \%$ & $45 \%$ \\
\hline \multicolumn{8}{|l|}{ LS } \\
\hline Objective Risk * & High & High & Mod & Mod & High & Mod & \\
\hline $\begin{array}{c}\text { Risk to Farming } \\
\text { Practices } \\
\text { M (SD) }\end{array}$ & $\begin{array}{l}1.00 \\
(0.0)\end{array}$ & $\begin{array}{c}1.10 \\
(0.32)\end{array}$ & $\begin{array}{c}1.05 \\
(0.16)\end{array}$ & $\begin{array}{c}1.32 \\
(0.64)\end{array}$ & $\begin{array}{l}1.00 \\
(0.0)\end{array}$ & $\begin{array}{c}1.25 \\
(0.50)\end{array}$ & $\begin{array}{c}1.11 \\
(0.36)\end{array}$ \\
\hline $\begin{array}{l}\text { Risk to Income } \\
\text { M (SD) }\end{array}$ & $\begin{array}{l}1.00 \\
(0.0)\end{array}$ & $\begin{array}{c}1.30 \\
(0.95)\end{array}$ & $\begin{array}{c}1.35 \\
(0.94)\end{array}$ & $\begin{array}{c}1.45 \\
(0.72)\end{array}$ & $\begin{array}{l}1.00 \\
(0.0)\end{array}$ & $\begin{array}{c}1.25 \\
(0.50)\end{array}$ & $\begin{array}{c}1.24 \\
(0.68)\end{array}$ \\
\hline Percentage adapting & $0 \%$ & $0 \%$ & $20 \%$ & $45 \%$ & $0 \%$ & $0 \%$ & $13 \%$ \\
\hline
\end{tabular}

* 0-1 cm/year = Low; 1-2 cm/year = Mod; 2+ cm/year = High (Source: Erban, Gorelick and Zebker, 2014)

** Elevation (meters above sea level) $>2$ = Low; $1-2=$ Mod; $0-1=$ High; $<0=$ Very High.

\subsubsection{SLR: Knowledge, Risk Perception and Adaptation}

- Knowledge and risk perception. Only actual observation of SLR led to higher levels of risk perception. The 36 people who reported having observed SLR were more likely than the 17 who had not to perceive it as a risk to their farming practices (MannWhitney $\mathrm{U}=441, p=0.005)$ and to their income $(\mathrm{U}=452, p=0.002)$. However, neither simply 'having heard about' SLR nor being able to identify the correct causes led to greater concern. The 48 people who had heard about SLR were not more likely than the 5 people who had not to perceive it as a risk to their farming practices $(U=180$, $p=0.069$ exact significance) or their income ( $\mathrm{U}=182.5, p=0.055)$. The 17 people who correctly understood the causes of SLR were not more likely than the 36 who had not to perceive it as a risk to their farming practices $(U=281.5, p=0.607)$ and to their income $(\mathrm{U}=276, p=0.532)$.

- Risk perception and adaptation. Adaptations to SLR were more likely to be reported by farmers reporting higher levels of perceived risk to farming practices (ChiSq Linear Trend Test $(\mathrm{DF}=1)=3.88, p=0.049)$ and to income $($ ChiSq Linear Trend Test $(\mathrm{DF}=1)$ $=5.11, p=0.024)$. See Table 6 .

- Knowledge and adaptation. Farmers who correctly identified the causes of SLR were more likely to report adaptations $(12 / 17$; Fisher's Exact $=0.018)$. Neither simply 'having heard about' SLR nor personally observing it was associated with more adaptations. Of farmers reporting having heard of SLR (48/53), 23 of 48 reported adaptations, not significantly different from those who had not heard of it (Fisher's Exact $=0.362)$. Of farmers who did not report observing SLR, 29.4\% $(5 / 17)$ nonetheless reported adaptations, compared to $52.8 \%(19 / 36)$ who had reported observations; this difference was not significant (Fisher's Exact $=0.145$ ). 


\subsubsection{LS: Knowledge, Risk Perception and Adaptation}

- Knowledge and risk perception. Only actual observation with LS led to higher levels of risk perception. The 12 people who had observed LS were more likely than the 41 who had not to perceive it as a risk to their farming practices $(\mathrm{U}=313, p=0.01)$ and to their income $(\mathrm{U}=352.5, p=0.000)$. The 44 people who had heard about LS were not more likely than the 9 people who had not to perceive it as a risk to their farming practices $(\mathrm{U}=225, p=0.245)$ or their income $(\mathrm{U}=234, p=0.171)$. The 19 people who correctly understood the causes of LS were not more likely than the 34 who had not to perceive it as a risk to their farming practices $(U=293, p=0.312)$ and to their income $(\mathrm{U}=303.5, p=0.561)$.

- Risk perception and adaptation. In terms of adaptation, neither farmers reporting higher levels of risk perception to farming practices (ChiSq Linear Trend Test $(\mathrm{DF}=1)=0.628, p=0.428)$ nor to income $($ ChiSq Linear Trend Test $(\mathrm{DF}=1)=0.654$, $p=0.419$ ) were more likely to report adaptations (Table 6). The farmers in Khanh Bin Tay (the commune with the most extensive freshwater polder system in our study) were significantly more likely to report adapting to LS than those of the other communes (Fisher's Exact Test $=10.8, p=0.011$ ). While farmers across the province reported adding soil to embankments, only the farmers in Khanh Binh Tay reported using bulldozers to add soil to the bottoms of their fields. Khanh Binh Tay, with its freshwater polder system, may be more susceptible to saline intrusion due to its coastal location.

- Knowledge and adaptation. Farmers reporting that they had directly observed LS (12/53) were more likely to report having made adaptations (9/12 vs. $15 / 41)$ $($ Fisher's Exact $=0.000)$. However, neither farmers who reported having heard of LS $(44 / 53)$ (Fisher's Exact $=0.334)$ nor those with a correct understanding of LS $(19 / 53)$ (Fisher's Exact $=1.00$ ) were more likely to report adaptations.

\section{Discussion}

Adaptation to climate change will always require dealing with high levels of uncertainty. As one approach to reducing this uncertainty, we sought to focus on regions on the 'front line' of climate change adaptation. Such regions allow us to observe how climate change is unfolding and the lessons learned here are likely to benefit other areas that will face the same difficult choices. We modeled the combined effects of LS and SLR in Vietnam's Ca Mau province using the most accurate extant elevation data and found that current estimates of submersion are too conservative. In fact, $43 \%$ of the provinceincluding its geographic center and the capital city of $\mathrm{Ca} \mathrm{Mau}-$ is likely to be at risk of submersion by 2030 , and $75 \%$ by 2050 . As much of the province already approaches the condition of a saltwater swamp, the last window of opportunity to either adapt or implement a planned retreat may have already closed.

Strikingly, however, interviews with the farmers demonstrate that they are largely unaware of the imminence of these threats and do not fully comprehend the nature and magnitude of the underlying processes. They are, instead, focused primarily on responding to day-by-day threats to their crops, as is true of most farmers, particularly in developing countries. Motivated by the opportunities inherent in their developmental trajectory, their actions (particularly, groundwater extraction) thus continue to hasten the demise of economic activity in the province.

\subsection{Objective Risks: Combined Effects of LS and SLR}

Our results differ markedly from those of Kulp and Strauss [4], which used AI to correct errors inherent in satellite-based digital elevation models. According to their AI-corrected coastal DEM, the entire Mekong Delta will be submerged by 2050 from the impact of SLR alone. This overestimates the impact of SLR on the delta [5]. Three possible error sources may explain their overestimations. First, they used a single common vertical reference for the entire planet (WGS84). Best practice calls for use of a local 
vertical datum, which enables more accurate elevation measurement as it accommodates differences in sea surface height along the geoid surface $[5,26]$. Further, their method of correction used AI neural networks trained on airborne lidar-derived elevation data for the US only. Consequently, the "23-dimensional vector of known attributes at the target location" used to correct the satellite-based DEM was based on attributes in the United States (e.g., US vegetation types, canopy heights and building structures and shapes), which may not correspond to those in other parts of the world. Finally, their airborne lidar-derived measures were not benchmarked against ground-based elevation data. Lidarderived measures are known to be less accurate than ground-based measurement by an estimated 17 to $26 \mathrm{~cm}[5,39]$. The current study used Vietnamese government ground-based measurements [5].

Our findings are largely consistent with Minderhoud et al. [5], as we used the same Topo DEM, but differ in two ways. First, whereas Minderhoud et al., applied projections of $20 \mathrm{~cm}, 50 \mathrm{~cm}$ and $80 \mathrm{~cm}$ of SLR across the entire surface of the study area, our study combined global SLR projections with different LS projections based on local compaction rates. Second, as our study was concerned with societal responses, we projected forward by 16 and 36 years to put the estimates onto a timeline.

We found faster rates of submersion than Minderhoud at al. [8], possibly because we used estimates of the effects of absolute SLR in the delta region from MONRE [6] while Minderhoud et al. used the more conservative IPCC mid-range projections (RCP 4.5). In addition, that paper assumed that, across the entire delta, subsidence due to natural compaction will be counterbalanced by gains due to new sediment deposits. However, subsidence varies within the delta based on 'subsurface architecture and composition' and subsidence in Ca Mau province is higher due to greater sediment compressibility, lower levels of aquifer recharge and the greater thickness of the aquifer system in the south [8] (pp. 8-10).

What are the implications of our projections for farming in Ca Mau? Currently, most remaining rice cultivation takes place in the northern ecozone, which also contains the protected Melaleuca forest. By 2030, more than half of this ecozone will be at risk of submersion, including all areas where rice is currently cultivated [40]. Additionally, increased salinity and the eventual disappearance of the freshwater Melaleuca forest area will result in a loss of biodiversity and of the economic activities associated with the forest (e.g., tourism, logging) [41]. The remainder of this ecozone will be less than $50 \mathrm{~cm}$ above sea level, rendering it highly vulnerable to flooding from storm surge and extreme weather events and subsequent salinization.

The northeastern ecozone, which includes Ca Mau city and additional rice growing polder system zones, is sinking at the fastest rate. The costs required to protect infrastructure, particularly in built up areas such as Ca Mau city, where a ring of dykes and the use of pumps will be required [42], are likely to be substantial [32,43]. Areas engaged in intensive aquaculture will face longer flood durations, greater salinization, and greater accumulations of pollution if water evacuation flows are reduced. The southern ecozone, particularly along the southern coastal ridge, has the highest elevation and is thus less vulnerable. However, much of this region is a protected mangrove area [44], which cannot be used for intensive aquaculture.

We emphasize that our estimates are conservative. First, we chose the lowest end of the range of subsidence rates put forward by Erban, Gorelick and Zebker [9]. Second, we did not include the secondary subsidence effect posited by Minderhoud et al. [25]. As AQC conversions started to occur around 2000 and there is a lag of approximately 20 years before secondary subsidence effects occur, the period from 2020 will likely see increased compaction rates. Finally, we used an increase of $30 \mathrm{~cm}$ for SLR to 2050 [6], an estimate of the predicted nonlinear trajectory of SLR that is believed to be low $[3,23]$. 


\subsection{The 'Embeddedness' of Subjective Perceptions}

Many studies have argued for the importance of local-level adaptation to climate change $[29,30,45]$. Some have emphasized the role of farmers as "key innovation actors", who, based on their own 'experiential learning,' develop successful livelihood strategies [31]. Our findings support the importance of considering local context in trying to understand local adaptive responses. Phenomena that do not clearly and directly impact routine farming practices attract little attention and concrete experience is of greater importance to risk perception than the 'awareness' generated through educational campaigns. Risk perception, in turn, was highly associated with adaptive response. However, this does not mean that local knowledge leads to optimal adaptive solutions. In our study, ranking of perceived threats did not match objective rankings of threat severity, suggesting that farmers are not adapting to the gravest problems. We suggest two reasons for this. First, farmers as economic agents tend to heavily 'discount' future outcomes and are generally better at innovating in response to temporally proximal factors and incentives than to temporally distant threats [46]. Thus, as has been found in other contexts, farmers are primarily concerned with "shorter term, atypical events" and "less troubled by ... longer term shifts" [47]. A second reason is that some phenomena, such as LS, are simply difficult to perceive and do not enter into the thinking of farmers in the course of their daily farming practices. Although representing the most critical threat to the region, LS was lowest on the list when farmers were not directly asked about it. Subsidence seems to be essentially 'invisible' in an area characterized by low elevation, regular flooding, and widespread salinization. Due to these two tendencies, farmers may be poorly equipped to respond to such long-term, underlying threats.

This raises a methodological point. In our interviews, we asked farmers to report any changes they had observed before asking them specifically about SLR and LS, allowing us to capture what was salient to the farmers themselves. Had we not done so, our results would have suggested that the two problems are more central in the thinking of the farmers than they actually are. Future studies should be careful to examine the full set of considerations motivating the daily practices of farmers.

Farmers in our study were not focused on SLR and LS but on solving the problems associated with their paths of economic development. For shrimp farmers, the transition to AQC required large amounts of freshwater. As Ca Mau is south of the Mekong's distributary branches, the water from the latter was not available. Initially, ponds were developed by adding liners to former rice fields and filling them with water from the canals that had hitherto served rice production. However, the accumulation of waste from the shrimp, pesticides and shrimp feed led to eutrophication and pollution requiring regular drainage and circulation of new, cleaner water. Farmers drained the polluted water into the canals, which could then no longer be used to refresh the ponds. Consequently, wells to extract groundwater became obligatory and are now ubiquitous—and still increasing - in much of the province [9].

Many of the interviewed shrimp farmers reported declining yields and increasing costs due to pollution and disease. One farmer in Dinh Binh reported that "in the past, we would put 50,000 breeders and we didn't even have to feed them. Now we can only put 10,000 or 20,000 and we have to feed them because the environment has changed and cannot support so many." Another farmer in the same commune told us:

"I tried industrial shrimp farming. In the first several years, I succeeded, but then I failed. The government encouraged us to expand our ponds, but when we lost yields. They didn't support us, they just gave us a little medicine to prevent shrimp disease, but not all of us received it. I changed from rice to shrimp because of government policy, and I made more profits, so I don't think I'll change back to rice... Salt intrusion is occurring so we cannot grow paddy rice anymore."

This case provides a good illustration of the phenomenon, characteristic of the region, in which early gains from intensification were soon lost to its side effects-eutrophication, pollution and salinization. Six out of ten of the farmers in the same commune of Dinh Binh 
mentioned possible government plans to revert to rice farming through the construction of a new polder system. However, other farmers felt that this was unlikely given previous government policies and the increasing salinization of the soil.

By contrast, for the integrated shrimp-mangrove farmers, the problem is the limitations imposed by the government. Three of ten farmers practicing integrated shrimp farming within the protected mangrove forest specifically mentioned a desire to convert to intensive aquaculture and complained about government prohibitions preventing them from doing so. It is clear then, in an area where mangrove deforestation is already a serious problem [48], that farmer innovations, far from enhancing sustainability, would likely further disrupt it.

Finally, rice farmers within the polder system zones in An Xuyen and Khanh Binh Tay wanted to make the transition from rice to AQC to pursue higher profits. In An Xuyen, two out of five rice farmers wanted to switch to polyculture; and one practicing rice-shrimp polyculture wanted to switch entirely to shrimp. Five of ten farmers in the Khanh Binh Tay polder system also wanted to switch to rice-shrimp aquaculture; as one farmer put it "Shrimp would bring greater profits ... but we are allowed to grow only rice." Such a transition of course, would entail further groundwater extraction intensifying the problem of LS.

Our findings suggest that, while farmers do indeed innovate, their innovations are directed first and foremost towards economic development, and not climate change adaptation. Indeed, as with groundwater extraction in $\mathrm{Ca} \mathrm{Mau,} \mathrm{their} \mathrm{innovations} \mathrm{may} \mathrm{exacerbate}$ problems associated with climate change.

\subsection{Limitations and Suggestions for Future Research}

There were limitations to our study. Our purpose in this study was to arrive at an estimate of the land at risk of inundation based on the combined effects of LS and SLR. However, we were unable to obtain more accurate ground-based measurements of land compaction. Hopefully, future research will make higher-resolution data publicly available. Future studies should also continue to investigate factors such as changes in temperature and rainfall patterns, land use patterns with their current and planned physical infrastructures [49] (p. 4), as well as salinization, water pollution and soil acidification, to better understand this region's likely trajectory. Further, we did not include the effects of waves, tidal dynamics and storm surge that can easily double the height of the high-water mark [50]. More studies that consider combined effects, such as those of SLR and LS in deltas around the world, are also needed. As Carew-Reid notes, there is a use for a 'rapid assessment approach' to bring about the timely "downscaling of global knowledge" into information that fits local planning needs [49] (p. 3).

At the same time, effectively communicating such information to farmers in a way that is helpful requires, as a starting point, a clear understanding of their own perceptions and adaptive responses. Investigating these was the second main purpose of our study. There were also limitations here. Although we were careful to include both rice and shrimp farmers along the coast and inland, the limited sample size and the non-representative nature of our sample prevent us from making broader generalizations within the province or across the delta. As other factors may have shaped their perceptions and adaptive responses (e.g., distance from the coast, erosion, mangrove deforestation), future research with larger, representative samples should consider such contextual factors and possibly extend our findings to other parts of the delta and beyond in a more generalizable form. More informed insight into farmer perspectives can only benefit the design of future outreach and education programs.

\section{Conclusions}

The magnitude and imminence of the risks facing $\mathrm{Ca}$ Mau province are greater than is allowed for in the literature. Farmers in the region, however, are focused not on these risks, but on short term problems in production. This reflects the broader contradiction 
mentioned in our title: economic reforms designed to generate development are incompatible with climate change adaptation. The core of the problem in Ca Mau is that adaptation would require a reduction in groundwater extraction and, consequently, a decline in economic activity. Such difficult choices are certain to be common in a growing number of regions. While it is likely too late for adaptation in Ca Mau, the same trends are also emerging in other parts of the Mekong Delta. What is urgently needed is an explicit focus on the issue of long-term sustainability of farming in the delta and other similar deltas, with particular focus on water management. This is primarily an economic issue, likely to involve government coordination.

There is also an educational issue involved, regarding overcoming the difficulty farmers have in both comprehending the abstract processes associated with climate change and land subsidence, and in assigning the appropriate emotional weight or degree of concern to these threats. Our study suggests that current educational practices designed to spur adaptation have failed to elevate the degree of perceived risk to appropriate levels. Future campaigns need to find a way to connect existing impacts of land subsidence with the farming practices that are contributing to it, while emphasizing the imminent worsening of the situation. As our study in Ca Mau demonstrates, if farmers continue to pursue their own short term livelihood strategies without also engaging in explicit long-term planning, they are likely to exacerbate the deeper underlying problems.

Supplementary Materials: The following are available online at https://www.mdpi.com/article/10 .3390/atmos12091160/s1, Figure S1: GIS Shapefiles and Rasters Workflow, Figure S2: Flowchart for Coastal Flooding Simulation, Supplementary Materials 3: Questionnaire in English and Vietnamese.

Author Contributions: Conceptualization, B.D.G., T.M.N.L., T.T.M.N., T.T.H.N., N.U.M.V. and J.P.L.; methodology, B.D.G. and J.P.L.; software, B.D.G.; validation, B.D.G. and J.P.L.; formal analysis, B.D.G., T.M.N.L., T.T.M.N., T.T.H.N., N.U.M.V. and J.P.L.; investigation, B.D.G., T.M.N.L., T.T.M.N., T.T.H.N., N.U.M.V. and J.P.L.; resources, B.D.G., T.M.N.L., T.T.M.N., T.T.H.N., N.U.M.V. and J.P.L.; data curation, B.D.G. and J.P.L.; writing—original draft preparation, B.D.G., T.M.N.L., T.T.M.N., T.T.H.N., N.U.M.V. and J.P.L.; writing-review and editing, B.D.G. and J.P.L.; visualization, B.D.G. and J.P.L.; supervision, B.D.G. and J.P.L.; project administration, B.D.G. and J.P.L.; funding acquisition, not applicable. All authors have read and agreed to the published version of the manuscript.

Funding: This research received no external funding.

Institutional Review Board Statement: Ethical review and approval for this type of study were not required within our institutional setting.

Informed Consent Statement: Informed consent was obtained from all subjects involved in the study.

Data Availability Statement: Data will be made available upon request.

Acknowledgments: We would like to thank the anonymous reviewers of this manuscript for their constructive suggestions. We are also deeply grateful to Nicky Chen for providing administrative support.

Conflicts of Interest: The authors declare no conflict of interest.

\section{References}

1. General Statistics Office of Vietnam. Statistical Data. Available online: http://www.gso.gov.vn/Default_en.aspx?tabid=766 (accessed on 10 April 2020).

2. Hens, L.; Thinh, N.A.; Hanh, T.H.; Cuong, N.S.; Lan, T.D.; Le, D.T. Sea-level rise and resilience in Vietnam and the Asia-Pacific: A synthesis. Vietnam. J. Earth Sci. 2018, 40,127-153. [CrossRef]

3. Intergovernmental Panel on Climate Change (IPCC). IPCC Special Report on the Ocean and Cryosphere in a Changing Climate; Weyer, N.M., Pörtner, H.-O., Roberts, D.C., Masson-Delmotte, V., Zhai, P., Tignor, M., Poloczanska, E., Mintenbeck, K., Alegría, A., Nicolai, M., et al., Eds.; Intergovernmental Panel on Climate Change (IPCC): Geneva, Switzerland, 2019.

4. Kulp, S.A.; Strauss, B.H. New elevation data triple estimates of global vulnerability to sea-level rise and coastal flooding. Nat. Commun. 2019, 10, 4844. [CrossRef] [PubMed] 
5. Minderhoud, P.S.J.; Coumou, L.; Erkens, G.; Middelkoop, H.; Stouthamer, E. Mekong delta much lower than previously assumed in sea-level rise impact assessments. Nat. Commun. 2019, 10, 3847. [CrossRef] [PubMed]

6. Ministry of Natural Resources and Environment (MONRE). Climate Change, Sea Level Rise Scenarios for Vietnam. 2016. Available online: http:/ / www.imh.ac.vn/files/doc/2017/CCS\%20final.compressed.pdf (accessed on 1 September 2021).

7. Nhung, T.T.; Le Vo, P.; van Nghi, V.; Bang, H.Q. Salt intrusion adaptation measures for sustainable agricultural development under climate change effects: A case of Ca Mau Peninsula, Vietnam. Clim. Risk Manag. 2019, 23, 88-100. [CrossRef]

8. Minderhoud, P.; Middelkoop, H.; Erkens, G.; Stouthamer, E. Groundwater extraction may drown mega-delta: Projections of extraction-induced subsidence and elevation of the Mekong delta for the 21st century. Environ. Res. Commun. 2020, 2, 011005. [CrossRef]

9. Erban, L.E.; Gorelick, S.M.; Zebker, H.A. Groundwater extraction, land subsidence, and sea-level rise in the Mekong Delta, Vietnam. Environ. Res. Lett. 2014, 9, 084010. [CrossRef]

10. Karlsrud, K.; Tunbridge, L.; Khanh, N.Q.; Dinh, N.Q. Preliminary results of land subsidence monitoring in the Ca Mau Province. In Proceedings of the International Association of Hydrological Sciences (IAHS), Tenth International Symposium on Land Subsidence, Delft, The Netherlands, 17-21 May 2021; Volume 382, pp. 111-115.

11. Smajgl, A.; Toan, T.Q.; Nhan, D.K.; Ward, J.F.; Trung, N.H.; Tri, L.Q.; Tri, V.P.D.; Vu, P.T. Responding to rising sea levels in the Mekong Delta. Nat. Clim. Chang. 2015, 5, 167-174. [CrossRef]

12. Environmental Justice Foundation (EJF). Risky Business: Vietnamese Shrimp Aquaculture-Impacts and Improvements. 2003 Available online: http:/ / www.vliz.be/en/imis? module=ref\&refid=203980\&printversion=1\&dropIMIStitle=1 (accessed on 1 September 2021).

13. Nguyen, T.A.T.; Nguyen, K.A.T.; Jolly, C. Is super-intensification the solution to shrimp production and export sustainability? Sustainability 2019, 11, 5277. [CrossRef]

14. Sen Nag, O. Top Fish and Seafood Exporting Countries. 2017. Available online: https://www.worldatlas.com/articles/top-fishand-seafood-exporting-countries.html (accessed on 1 September 2021).

15. Sen Nag, O. Top Rice Exporting and Importing Countries. 2017. Available online: https://www.worldatlas.com/articles/toprice-exporting-and-importing-countries.html (accessed on 1 September 2021).

16. Biggs, D. Fixing the Delta: History and the Politics of Hydraulic Infrastructure Development and Conservation in the Mekong Delta. In Environmental Change and Agricultural Sustainability in the Mekong Delta; Steward, M.A., Coclania, P.A., Eds.; Springer Science \& Business Media: Dordrecht, The Netherlands, 2011; Volume 45, pp. 35-44. ISBN 978-940-070-933-1.

17. Olson, K.R.; Morton, L.W. Polders, dikes, canals, rice, and aquaculture in the Mekong Delta. J. Soil Water Conserv. 2018, 73, 83A-89A. [CrossRef]

18. Scherr, S.; Mankad, K.; Jaffee, S.; Negara, C. Steps Toward Green: Policy Responses to Commodity Agriculture in East and Southeast Asia; World Bank Group: Washington, DC, USA; EcoAgriculture Partners: Oakton, VA, USA, 2015. Available online: http://www. landscapes.org/publication/steps-toward-green-policy-responses-to-commodity-agriculture-in-east-and-southeast-asia/ (accessed on 1 September 2021).

19. Van Quach, A.; Murray, F.; Morrison-Saunders, A. The vulnerability of shrimp farming income to climate change events. Int. J. Clim. Chang. Strat. Manag. 2017, 9, 261-280. [CrossRef]

20. Ministry of Agriculture and Rural Development (MARD). Mekong Delta Integrated Climate Resilience and Sustainable Livelihoods Project, Regional Environmental Assessment Report; Ministry of Agriculture and Rural Development (MARD): Hanoi, Vietnam, 2016.

21. CGIAR Research Centers in Southeast Asia. The Drought and Salinity Intrusion in the Mekong River Delta of Vietnam, Assessment Report. 2016. Available online: https:/ /cgspace.cgiar.org/handle/10568/75633\%0Apapers3://publication/uuid/1F44F90CA3AD-4202-B9EE-EDB184F85B37 (accessed on 1 September 2021).

22. Nguyen, H.S.; Bui, T.Y.; Sebastian, L. Development of Climate-Related Risk Maps and Adaptation Plans (Climate Smart MAP) for Rice Production in Vietnam's Mekong River Delta; CGIAR Research Program on Climate Change, Agriculture and Food Security (CCAFS): Wageningen, The Netherlands, 2018. Available online: https:/ /cgspace.cgiar.org/rest/bitstreams/148994/retrieve (accessed on 1 September 2021).

23. The U.S. Global Change Research Program (USGCRP). Impacts, Risks, and Adaptation in the United States: Fourth National Climate Assessment, Volume II. 2018. Available online: https: / / nca2018.globalchange.gov/ (accessed on 1 September 2021).

24. Minderhoud, P.S.J.; Erkens, G.; Pham, V.H.; Bui, V.T.; Erban, L.; Kooi, H.; Stouthamer, E. Impacts of 25 years of groundwater extraction on subsidence in the Mekong delta, Vietnam. Environ. Res. Lett. 2017, 12, 064006. [CrossRef]

25. Minderhoud, P.; Coumou, L.; Erban, L.; Middelkoop, H.; Stouthamer, E.; Addink, E. The relation between land use and subsidence in the Vietnamese Mekong delta. Sci. Total. Environ. 2018, 634, 715-726. [CrossRef] [PubMed]

26. Gesch, D.B. Best practices for elevation-based assessments of sea-level rise and coastal flooding exposure. Front. Earth Sci. 2018, 6, 230. [CrossRef]

27. Kulp, S.; Strauss, B.H. Global DEM errors underpredict coastal vulnerability to sea level rise and flooding. Front. Earth Sci. 2016, 4, 36. [CrossRef]

28. Yamazaki, D.; Ikeshima, D.; Tawatari, R.; Yamaguchi, T.; O’Loughlin, F.; Neal, J.C.; Sampson, C.C.; Kanae, S.; Bates, P.B. A high-accuracy map of global terrain elevations. Geophys. Res. Lett. 2017, 44, 5844-5853. [CrossRef]

29. Le Dang, H.; Li, E.; Nuberg, I.; Bruwer, J. Farmers' perceived risks of climate change and influencing factors: A study in the Mekong Delta, Vietnam. Environ. Manag. 2014, 54, 331-345. [CrossRef] 
30. Le Dang, H.; Li, E.; Nuberg, I.; Bruwer, J. Understanding farmers' adaptation intention to climate change: A structural equation modelling study in the Mekong Delta, Vietnam. Environ. Sci. Policy 2014, 41, 11-22. [CrossRef]

31. Tran, T.A.; Rodela, R. Integrating farmers' adaptive knowledge into flood management and adaptation policies in the Vietnamese Mekong Delta: A social learning perspective. Glob. Environ. Chang. 2019, 55, 84-96. [CrossRef]

32. Takagi, H.; Thao, N.D.; Anh, L.T. Sea-level rise and land subsidence: Impacts on flood projections for the Mekong delta's largest city. Sustainability 2016, 8, 959. [CrossRef]

33. Asian Development Bank (ADB). Climate Risks in the Mekong Delta: Ca Mau and Kien Giang Provinces of Viet Nam; Asian Development Bank (ADB): Manila, Philippines, 2013.

34. Wassmann, R.; Phong, N.D.; Tho, T.Q.; Hoanh, C.T.; Khoi, N.H.; Hien, N.X.; Vo, T.B.T.; Tuong, T.P. High-resolution mapping of flood and salinity risks for rice production in the Vietnamese Mekong Delta. Field Crop. Res. 2019, 236, 111-120. [CrossRef]

35. Tran, D.D.; van Halsema, G.; Hellegers, P.J.; Hoang, L.P.; Ludwig, F. Long-term sustainability of the Vietnamese Mekong Delta in question: An economic assessment of water management alternatives. Agric. Water Manag. 2019, 223, 105703. [CrossRef]

36. International Centre for Environmental Management (ICEM). Delta Maps: Compaction-Based Subsidence. 2015. Available online: https:/ /icem.com.au/slide/delta-maps-compaction-based-subsidence/ (accessed on 1 September 2021).

37. Malik, A.; Abdalla, R. Geospatial modeling of the impact of sea level rise on coastal communities: Application of Richmond, British Columbia, Canada. Model. Earth Syst. Environ. 2016, 2, 146. [CrossRef]

38. National Oceanic and Atmospheric Administration (NOAA). Mapping Coastal Inundation Primer; National Oceanic and Atmospheric Administration (NOAA): Silver Spring, MA, USA, 2012; pp. 1-28.

39. Hodgson, M.E.; Bresnahan, P. Accuracy of airborne lidar-derived elevation. Photogramm. Eng. Remote Sens. 2004, 70, 331-339. [CrossRef]

40. Tran, H.; Tran, T.; Kervyn, M. Dynamics of land cover/land use changes in the Mekong delta, 1973-2011: A remote sensing analysis of the Tran Van Thoi District, Ca Mau Province, Vietnam. Remote Sens. 2015, 7, 2899-2925. [CrossRef]

41. Tran, D.B.; Dargusch, P.; Moss, P.; Hoang, T.V. An assessment of potential responses of Melaleuca genus to global climate change. Mitig. Adapt. Strat. Glob. Chang. 2012, 18, 851-867. [CrossRef]

42. Minderhoud, P.S.J.; Hlavacova, I.; Kolomaznik, J.; Neussner, O. Towards unraveling total subsidence of a mega-delta-The potential of new PS InSAR data for the Mekong delta. In Proceedings of the International Association of Hydrological Sciences (IAHS), Tenth International Symposium on Land Subsidence, Delft, The Netherlands, 17-21 May 2021; Volume 382, pp. 327-332.

43. Mackay, P.; Russell, M. Climate change impact and adaptation study in the Mekong Delta-Part A. In Climate Change Vulnerability $\mathcal{E}$ Risk Assessment Study for Ca Mau and Kien Giang Provinces, Vietnam; Institute of Meteorology, Hydrology and Environment of Vietnam (IMHEN): Hanoi, Vietnam, 2011; p. 250.

44. Vietnam Environment Protection Agency (Vietnam EPA). Overview of Wetlands Status in Viet Nam Following 15 Years of Ramsar Convention Implementation; Vietnam Environment Protection Agency (Vietnam EPA): Hanoi, Vietnam, 2005.

45. Resurreccion, B.P.; Sajor, E.E.; Fajber, E. Climate Adaptation in Asia: Knowledge Gaps and Research Issues in South East Asia, Full Report of the South East Asia Team; Institute for Social and Environmental Transition-International (ISET-International): Boulder, CO, USA; ISET-Nepal (Institute for Social and Environmental Transition-Nepal): Kathmandu, Nepal, 2008. Available online: http:/ /idl-bnc.idrc.ca/dspace/handle/10625/41543 (accessed on 1 September 2021).

46. Loewenstein, G.; Prelec, D. Anomalies in intertemporal choice: Evidence and an interpretation. Q. J. Econ. 1992, 107, 573-597. [CrossRef]

47. Gustafson, S.; Cadena, A.J.; Hartman, P. Adaptation planning in the Lower Mekong Basin: Merging scientific data with local perspective to improve community resilience to climate change. Clim. Dev. 2016, 10, 152-166. [CrossRef]

48. Veettil, B.K.; Ward, R.D.; Quang, N.X.; Trang, N.T.T.; Giang, T.H. Mangroves of Vietnam: Historical development, current state of research and future threats. Estuar. Coast. Shelf Sci. 2019, 218, 212-236. [CrossRef]

49. Carew-Reid, J. Rapid Assessment of the Extent and Impact of Sea Level Rise in Viet Nam, Climate Change Discussion Paper 1; International Centre for Environmental Management (ICEM): Brisbane, Australia, 2008.

50. Karlsrud, K.; Vangelsten, B.V.; Frauenfelder, R. Subsidence and shoreline retreat in the Ca Mau Province-Vietnam causes, consequences and mitigation options. Geotech. Eng. 2017, 48, 26-32. 